\title{
NEGARA HUKUM INDONESIA KEBALIKAN NACHTWACHTERSTAAT
}

\author{
Zulkarnain Ridlwan
}

Dosen Bagian Hukum Tata Negara FH Universitas Lampung

\begin{abstract}
Abstrak
Tujuan penulisan ini adalah untuk mendeskripsikan konsep negara hukum Indonesia berdasarkan konstitusi yang pernah dan sedang berlaku di Indonesia. Berdasarkan tinjauan normatif dan perkembangan ketatanegaraan Indonesia disimpulkan bahwa sejak awal Republik Indonesia berdiri pilihan konsep negara hukum yang dicitakan adalah negara hukum demokratis yang secara aktif bertujuan untuk mewujudkan perlindungan terhadap segenap bangsa Indonesia dan seluruh tumpah darah Indonesia; memajukan kesejahteraan umum; mencerdaskan kehidupan bangsa; dan ikut serta memelihara ketertiban dunia yang berdasarkan kemerdekaan, perdamaian abadi dan keadilan sosial. Disamping itu, negara hukum Indonesia dipengaruhi Pancasila sebagai kumpulan nilai-nilai dasar yang disepakatu dan menjadi landasan praktek kedaulatan rakyat, yakni Ketuhanan Yang Maha Esa; Kemanusiaan Yang Adil dan Beradab; Persatuan Indonesia dan Kerakyatan yang dipimpin oleh hikmat kebijaksanaan dalam Permusyawaratan/Perwakilan; serta menciptakan keadilan sosial bagi seluruh rakyat Indonesia. Dengan demikian, Negara Hukum Indonesia yang dijalankan haruslah senantiasa memperhatikan aspek ketuhanan, kemanusiaan, persatuan, permusyawaratan dan keadilan. Meski pernah berganti konstitusi dan melakukan perubahan atas konstitusi yang berlaku, namun pilihan konsep negara hukum masih tetap sama yaitu negara hukum aktif atau dinamis dalam mewujudkan kesejahteraan rakyat. Konsep negara hukum demikian dipresentasikan sebagai welvaarstaat, yang adalah kebalikan negara penjaga malam (nachtwachterstaat).
\end{abstract}

\section{Kata Kunci : Negara Hukum, Indonesia, Nachtwachterstaat}

\section{A. PENDAHULUAN}

Ide negara hukum telah lama dikembangkan oleh para filsuf dari zaman Yunani Kuno. Plato, pada awalnya dalam "the Republic" berpendapat bahwa adalah mungkin mewujudkan negara ideal untuk mencapai kebaikan, yang berintikan kebaikan. Untuk itu kekuasaan harus dipegang oleh orang yang mengetahui kebaikan, yaitu seorang filosof (the philosopher king). Namun dalam bukunya "the Statesmen" dan "the Law", Plato menyatakan bahwa yang dapat diwujudkan adalah bentuk paling baik kedua (the second best) yang menempatkan supremasi hukum. Pemerintahan yang mampu mencegah kemerosotan kekuasaan seseorang adalah pemerintahan oleh hukum. Senada dengan Plato, tujuan Negara menurut Aristoteles adalah untuk mencapai kehidupan yang paling baik (the best life possible) yang dapat dicapai dengan supremasi hukum. Hukum adalah wujud kebijaksanaan kolektif warga Negara (collective wisdom), sehingga peran 
warga Negara diperlukan dalam pembentukannya. ${ }^{1}$

Jadi, sebagai sebuah konsep bernegara, negara hukum bukanlah sesuatu yang baru dalam pembicaraan mengenai bagaimana negara dijalankan dan dikelola. Pada abad 19 muncul gagasan tentang pembatasan kekuasaan pemerintah melalui pembuatan konstitusi, baik secara tertulis maupun tidak tertulis, selanjutnya diketahui tertuang dalam apa yang disebut konstitusi. Konstitusi tersebut memuat batasbatas kekuasaan pemerintah dan jaminan atas hak-hak politik rakyat, serta prinsip check and balances antar kekuasaan yang ada. Pembatasan konstitusi atas kekuasaan negara ini selanjutnya dikenal dengan istilah konstitusionalisme.

Konstitusionalisme kemudian memunculkan konsep rechstaat (dari kalangan ahli hukum Eropa Kontinental) atau rule of law (dari kalangan ahli hukum Anglo Saxon) yang di Indonesia diterjemahkan dengan Negara Hukum. Negara yang memiliki peran terbatas tersebut juga acap kali dijuluki sebagai nachtwachterstaat (negara penjaga malam). ${ }^{2}$

Menjelang pertengahan abad ke-20, konsep Negara hukum formal (klasik) yang dicirikan dengan peran negara yang terbatas digeser kearah gagasan baru bahwa pemerintah tidak hanya menjadi nachtwachterstaat, namun harus aktif melakukan upaya-upaya untuk membangun kesejahteraan

\footnotetext{
${ }^{1}$ Sabine, dalam Jimly Asshiddiqie, HTN dan Pilar-Pilar Demokrasi, (Jakarta: Konstitusi Press, 2006), hlm. 147.

${ }^{2}$ Moh. Mahfud MD, Hukum dan Pilar-Pilar Demokrasi. (Yogyakarta: Gama Media, 1999), hlm. 22-24.
}

rakyatnya. Tugas dan peranan Negara kemudian menjadi dinamis dan meluas jauh melewati batasbatas yang pernah diatur dalam demokrasi konstitusional abad ke-19. Gagasan demokrasi abad 20 ini lazim disebut welvaarstaat/ welfare state (negara kesejahteraan) atau "negara hukum material" (negara hukum modern).

Indonesia sebagai sebuah negara yang lahir pada abad ke-20, mengadopsi konsep bernegara hukum sesuai prinsip konstitusionalisme. Hal ini dapat dilihat dari kesepakatan (consensus) bangsa Indonesia sejak UUD 1945 sebagai konstitusi negara Indonesia ditetapkan. Kesepakatan inilah yang pada perkembangannya menjelma menjadi cita-cita bersama yang biasa juga disebut falsafah kenegaraan atau staatsidee (cita negara) yang berfungsi sebagai filosofische grondslag dan common platforms atau kalimatun sawa diantara sesama warga masyarakat dalam konteks kehidupan bernegara. ${ }^{3}$ Namun apakah konsep negara hukum yang diatur dalam konstitusi tersebut mengalami perkembangan atau bahkan pergantian arah perwujudannya seiring dengan pergantian dan perubahan konstitusi yang berlaku di Indonesia? Lalu bagaimanakah konsep negara hukum Indonesia tersebut?

\section{B. PEMBAHASAN}

Pemerintah yang demokratis di bawah Rule of Law merupakan pemikiran mengenai Negara Hukum modern yang pernah di cetuskan dalam konferensi oleh International

\footnotetext{
${ }^{3}$ Lihat Jimly Asshiddiqie, Konstitusi dan Konstitusionalisme Indonesia, (Jakarta: Sinar Grafika, 2010), hlm. 22.
} 
Commission of Jurists di Bangkok pada tahun 1965 yang menekankan pemahaman "the dynamic aspects of the Rule of Law in the modern age" (aspek-aspek dinamika Rule of Law dalam abad modern). Dikatakan bahwa ada 6 (enam) syarat-syarat dasar untuk terselenggaranya pemerintah yang demokratis dibawah Rule of Law, yaitu Perlindungan Konstitusional, Peradilan atau badanbadan kehakiman yang bebas dan tidak memihak, Pemilihan Umum yang bebas, Kebebasan menyatakan pendapat, Kebebasan berserikat/ berorganisasi dan beroposisi, dan Pendidikan kewarganegaraan. ${ }^{4}$

Undang-Undang Dasar negara kita menyebutkan bahwa Negara Republik Indonesia itu adalah Negara Hukum yang demokrasi (democratische rechtstaat) dan sekaligus adalah Negara Demokrasi yang berdasarkan atau hukum (constitutional democracy) yang tidak terpisahkan satu sama lain. ${ }^{5}$ Sebagaimana disebutkan dalam naskah perubahan UUD 1945 yang menyebutkan bahwa paham negara hukum sebagaimana tercantum dalam ketentuan Pasal 1 Ayat (3) berkaitan erat dengan paham negara kesejahteraan (welfare state) atau

4 Paulus E Lotulung, Kebebasan Hakim dalam Sistim Penegakan Hukum, Makalah disampaikan Pada Seminar Pembangunan Hukum Nasional VIII Tema "Penegakan Hukum dalam Era Pembangunan Berkelanjutan" Diselenggarakan Oleh Badan Pembinaan Hukum Nasional Departemen Kehakiman Dan Hak Asasi Manusia RI. Denpasar, 14 -18 Juli 2003, hlm. 3.

5 Jimly Asshiddiqie. Makalah Struktur Ketatanegaraan Indonesia Setelah Perubahan Keempat UUD 1945 disampaikan pada Seminar Pembangunan Hukum Nasional VIII Tema Penegakan Hukum Dalam Era Pembangunan Berkelanjutan. Denpasar, 2003, hlm. 3. paham negara hukum materiil sesuai dengan bunyi alenia keempat Pembukaan dan Ketentuan Pasal 34 UUD 1945. Pelaksanaan paham negara hukum materiil akan mendukung dan mempercepat terwujudnya negara kesejahteraan di Indonesia. ${ }^{6}$

Konsep Negara Hukum, selain bermakna bukan Negara Kekuasaan (Machtstaat) juga mengandung pengertian adanya pengakuan terhadap prinsip supremasi hukum dan konstitusi, dianutnya prinsip pemisahan dan pembatasan kekuasaan menurut sistem konstitusional yang diatur dalam undang-undang dasar, adanya jaminan-jaminan hak asasi manusia dalam undang-undang dasar, adanya prinsip peradilan yang bebas dan tidak memihak yang menjamin persamaan setiap warga negara dalam hukum, serta menjamin keadilan bagi setiap orang termasuk terhadap penyalahgunaan wewenang oleh pihak yang berkuasa.

Dalam paham negara hukum yang demikian itu, pada hakikatnya hukum itu sendirilah yang menjadi penentu segalanya sesuai dengan prinsip nomokrasi dan doktrin 'the rule of Law, and not of Man'. Dalam kerangka 'the rule of law' itu, diyakini adanya pengakuan bahwa hukum itu mempunyai kedudukan tertinggi (supremacy of law), adanya persamaan dalam hukum dan pemerintah (equality before the law), dan berlakunya asas legalitas dalam

\footnotetext{
${ }^{6}$ Majelis Permusyawaratan Rakyat Republik Indonesia, Hasil Perubahan dan Naskah Asli UUD 1945, dalam Panduan Pemasyarakatan Undang-Undang Dasar Negara Republik Indonesia Tahun 1945, (Jakarta: Sekretariat Jenderal MPR RI, 2005), hlm. 46.
} 
segala bentuknya dalam kenyataan praktek (due process of law).

Prinsip negara hukum idealnya dibangun dan dikembangkan bersama prinsip-prinsip demokrasi atau kedaulatan rakyat (democratische rechtsstaat). Sehingga hukum yang dimaksud tidak dibuat, ditetapkan, ditafsirkan dan ditegakkan dengan tangan besi berdasarkan kekuasaan belaka. Maka prinsip negara hukum tidak boleh ditegakkan dengan mengabaikan prinsip-prinsip demokrasi yang diatur dalam Undang-Undang Dasar. Puncak kekuasaan hukum itu diletakkan pada konstitusi yang pada hakikatnya merupakan dokumen kesepakatan tentang sistem kenegaraan tertinggi.

Hubungan antara demokrasi dan negara hukum dapat tercermin dalam penjabaran bahwa yang dapat menjamin secara konstitusional terselenggaranya pemerintah yang demokratis adalah adanya hukum yang menaunginya. Dengan kata lain demokrasi yang berada dibawah Rule of Law. Sedangkan syarat-syarat dasar untuk terselenggaranya pemerintahan yang demokratis di bawah Rule of Law ialah: ${ }^{7}$

1. Perlindungan konstitusional, dalam arti bahwa konstitusi, selain menjamin hak-hak individu, harus menentukan pula cara procedural untuk memperoleh perlindungan atas hak-hak yang dijamin.

2. Badan kehakiman yang bebas dan tidak memihak (independent and impartial tribunals).

3. Pemilihan umum yang bebas.

4. Kebebasan untuk menyatakan pendapat.

7 Miriam Budiardjo. Dasar-dasar Ilmu Politik, Edisi Revisi. (Jakarta: PT Gramedia Pustaka Utama, 2008), hlm. 116.
5. Kebebasan untuk berserikat/ berorganisasi dan beroposisi.

6. Pendidikan kewarganegaraan (civic education).

Jika merujuk pada ke enam hal tersebut dengan mengidentifikasi keberadaan dan prakteknya dalam negara Indonesia, maka dapat dikatakan bahwa Indonesia telah memenuhi syarat sebagai negara hukum yang melaksanakan demokrasi yang berdasarkan konstitusi.

Namun negara hukum seperti apakah yang dianut oleh Indonesia, belumlah terjabarkan secara eksplisit dalam UUD 1945. Apakah Indonesia menganut negara hukum aktif/ dinamis (dalam hal ini peran pemerintah sangat besar dalam penyelenggaraan negara). Ataukah menganut negara hukum formil dalam artian klasik, yang mengandung konsep bahwa semakin kecil peran pemerintah semakin baik, atau bahkan secara ekstrim hanya menjadi negara penjaga malam (nachtwachterstaat).

Konsep nachtwachterstaat dalam hal ini pada prakteknya hanya memberikan ruang kewenangan bagi negara untuk menyelesaikan masalah yang menyangkut kepentingan umum, sedangkan untuk kesejahteraan atau kepentingan pribadi diserahkan kepada pribadi masing-masing anggota masyarakat tanpa campur tangan negara.

Sejak kemerdekaannya, Indonesia punya pengalaman dalam pergantian dan perubahan konstitusi. UUD 1945 sebagai konstitusi negara, di tahun 1949 pernah digantikan Konstitusi Republik Indonesia Serikat (KRIS) yang kemudian dilanjutkan dengan Undang-Undang Dasar Sementara (UUDS) 1950 
hingga 1959. ${ }^{8}$ Setelah UUD 1945 kembali diberlakukan, hingga saat ini telah berubah sebanyak empat kali dalam rentang waktu 1999-2002. Pergantian dan Perubahan konstitusi ini pada kenyataannya tidak pernah menghilangkan klausul tujuan bernegara dan cita negara hukum yang dicantumkan dalam Mukaddimah/

Preambule/Pembukaan dan Batang Tubuh (Pasal-Pasal) Konstitusi.

\subsection{Konsep Negara Hukum Indonesia dalam UUD 1945 (kurun waktu pertama)}

Pada Pembukaan UUD 1945 yang ditetapkan oleh PPKI pada 18 Agustus 1945 memuat Paragraf yang mengatur konsep bernegara yang berbunyi:

"Kemoedian dari pada itoe oentoek membentoek suatoe Pemerintah negara Indonesia jang melindoengi segenap bangsa Indonesia dan seloeroeh toempah darah Indonesia dan oentoek memadjoekan kesedjahteraan oemoem, mencerdaskan kehidoepan bangsa, dan ikoet melaksanakan ketertiban doenia jang berdasarkan kemerdekaan, perdamaian abadi dan keadilan sosial, maka disoesoenlah Kemerdekaan Kebangsaan Indonesia itoe dalam soeatoe OendangOendang Dasar Negara Indonesia, jang terbentoek dalam soeatoe soesoenan

8 UUDS ini berlaku berdasarkan UndangUndang Republik Serikat Nomor 7 Tahun 1950 Tentang Perubahan Konstitusi Sementara Republik Indonesia Serikat Mendjadi Undang-Undang Dasar Sementara Republik Indonesia.
Negara Republik Indonesia jang berkedaoelatan rakjat dengan berdasarkan kepada Ketoehanan Jang Maha Esa, Kemanoesiaan Jang Adil dan Beradab, Persatoean Indonesia dan Kerakjatan jang dipimpin oleh hikmat kebidjaksanaan dalam Permoesyawaratan/ Perwakilan, serta dengan mewoedjoedkan soeatoe Keadilan sosial bagi seloeroeh rakjat Indonesia".

Adapun mengenai ketentuan bernegara Indonesia yang berdasarkan hukum, UUD 1945 (kurun waktu pertama) tidak menyebutkannya dalam PasalPasal. ${ }^{10}$ Aturan mengenai hal ini diatur dalam Penjelasan Otentik UUD 1945 yang berbunyi: "Negara Indonesia berdasar atas Hoekoem (Rechstaat), tidak berdasarkan atas kekoesaan belaka (Machstaat). ${ }^{11}$

Ketentuan dalam Penjelasan tersebut bersifat perbandingan, bahwa penyelenggaraan negara Indonesia yang dicita-citakan para founding fathers adalah rechstaat bukan machstaat. Dengan demikian, cita negara hukum sudah terkonsepkan dalam Konstitusi Pertama yang berlaku di Indonesia, meski letak substansinya hanya ada dalam Penjelasan Otentik. Hal ini menjelaskan bahwa pemikiran awal

9 Lihat RM. A.B Kusuma, Lahirnya Undang-Undang Dasar 1945 -Memuat Salinan Dokumen Otentik Badan Oentoek Menyelidiki Oesaha-Oesaha Persiapan Kemerdekaan-, (Jakarta: Fakultas Hukum Universitas Indonesia, 2009), hlm. 591.

${ }^{10}$ Pada masa kurun waktu pertama, Bagian Pasal-Pasal dalam UUD 1945 disebut Batang Tubuh.

11 Lihat RM. A.B Kusuma, Lahirnya Undang-Undang Dasar 1945.. Op.Cit., hlm. 598. 
pembentukan pemerintahan negara Indonesia diarahkan kepada penyelenggaraan pemerintahan yang mengedepankan hukum sebagai panglima, agar tidak terjebak pada dominasi otoritas pemerintah sebagai ribadi yang menjalankan kekuasaan bernegara tanpa mendasarkan pada hukum. Dengan demikian, harapan terwujudnya supremasi hukum diatas yang realitas sosial yang lain menjadi ruh perdana yang disematkan pada penyelenggara pemerintahan Negara Republik Indonesia.

Fakta ini juga menjelaskan bahwa pendapat umum tentang keadaan terbalik yang terjadi pada masa Orde Lama dan Orde Baru yang lebih mengedepankan dominasi pribadi Presiden sebagai "Penguasa Tunggal" penyelenggaraan negara adalah personal fault dari Presiden itu sendiri yang tidak menjalankan amanat konstitusi.

\subsection{Konsep Negara Hukum Indonesia dalam KRIS 1945}

Pada Mukaddimah KRIS 1949 memuat Paragraf yang mengatur konsep penyelenggaraan negara berdasarkan hukum yang berbunyi: ${ }^{12}$

"Kami bangsa Indonesia semendjak berpuluh-puluh tahun lamanja bersatu-padu dalam perdjuangan kemerdekaan, dengan senantiasa berhati-teguh berniat menduduki hak-hidup sebagai bangsa jang merdekaberdaulat. Kini dengan berkat dan rahmat Tuhan telah sampai kepada tingkatan sedjarah jang berbahagia dan luhur. Maka

12 Ibid., hlm. 605. Lihat juga dalam ejaan baru, dalam Moh. Mahfud MD, Demokrasi dan Konstitusi di Indonesia, (Jakarta: Rineka Cipta, 2003), hlm. 204. demi ini kami menjusun kemerdekaan kami itu dalam suatu Piagam negara jang berbentuk republik-federasi, berdasarkan pengakuan keTuhanan Jang Maha-Esa, perikemanusiaan, kebangsaan, kerakjatan dan keadilan sosial. Untuk mewudjudkan kebahagiaan kesedjahteraan perdamaian dan kemerdekaan dalam masjarakat dan negarahukum Indonesia Merdeka jang berdaulat sempurna."

Ketentuan di atas menjelaskan bahwa dalam konsepsi negara Republik Indonesia Serikatpun, penyelenggaraan negara diarahkan pada cita negara hukum dengan klausa “...Untuk mewujudkan ... negara hukum Indonesia Merdeka jang berdaulat sempurna". Klausa tersebut selanjutnya ditegaskan dalam penjabaran mengenai Bentuk Negara dan Kedaulatan, pada Pasal 1 ayat (1) yang berbunyi: "Republik Indonesia Serikat jang merdeka dan berdaulat jalah suatu negara-hukum jang demokrasi dan berbentuk federasi." Pasal ini menjelaskan bahwa bentuk negara hukum yang dicita-citakan pada masa berlakunya KRIS adalah negara hukum yang menganut dan mempraktekkan demokrasi sebagai pilihan penyelenggaraan negara. Dengan kata lain, konsep negara hukum pada masa ini adalah Negara Hukum Demokratis.

Lebih lanjut dalam tataran implementasinya, KRIS bahkan memberi penegasan bahwa dalam rangka membentuk supremasi hukum, diatur bahwa "Setiap orang jang ada didaerah Negara harus patuh kepada Undang-undang, termasuk aturan2 hukum jang tak 
tertulis, dan kepada penguasa2 jang sah dan jang bertindak sah". ${ }^{13}$

\subsection{Konsep Negara Hukum Indonesia dalam UUD 1950}

Pada Mukaddimah UUDS 1950 yang ditetapkan oleh Presiden Soekarno pada 15 Agustus 1950 memuat Paragraf yang mengatur konsep bernegara hukum yang berbunyi: "Maka demi ini kami menjusun kemerdekaan kami itu dalam suatu piagam Negara jang berbentuk republik-kesatuan, berdasarkan ke-Tuhanan Jang Maha Esa, peri-kemanusiaan, kebangsaan, kerakjatan dan keadilan sosial, untuk mewudjudkan kebahagiaan, kesedjahteraan, perdamaian dan kemerdekaan dalam masjarakat dan negara-hukum Indonesia Merdeka jang berdaulat sempurna".

Secara redaksional klausul cita negara hukum dalam UUDS 1950 masih sama dengan KRIS 1949 yakni "Negara-hukum Indonesia Merdeka jang berdaulat sempurna". Namun dalam penjabaran Pasalnya disebutkan sebuah bentuk konsepsi bernegara yang berbeda sesuai dengan semangat zaman untuk mengembalikan bentuk negara kepada kesatuan, hal ini sebagaimana disebutkan dalam Pasal 1 ayat (1) "Republik Indonesia jang merdeka dan berdaulat ialah suatu negarahukum jang demokratis dan berbentuk kesatuan". Klausa ini berubah seiring perubahan bentuk negara dari federasi kepada kesatuan. Namun demikian, cita supremasi hukum dalam tataran implementasinya, sebagaimana diatur dalam KRIS 1949 tetap dijiwai UUDS 1950 dengan Pasal 32 "Setiap orang jang di daerah Negara harus

\footnotetext{
${ }^{13}$ Pasal 31 KRIS
}

patuh kepada undang-undang termasuk aturan-aturan hukum jang tak tertulis, dan kepada penguasapenguasa."

Kesamaan yang dimiliki ketentuan dalam KRIS 1949 dan UUDS 1950 yaitu bahwa meski memiliki kesamaan cita untuk membentuk negara hukum yang demokratis, namun dalam pengaturan konsepsi implementasinya masih menunjuk kepatuhan yang dilakukan oleh 'setiap orang dalam Negara Indonesia' disamping kepada Undang-Undang -sebagai suatu produk hukum-, juga kepada penguasa, dalam hal ini pemerintah. Sehingga dapat diartikan bahwa meski Undang-Undang tidak dapat dikatakan mewakili hukum sebagai ruh cita mewujudkan negara hukum, namun kepatuhan terhadapnya menjadi salah satu tolok ukur perwujudan semangat negara hukum.

Penyandingan antara kepatuhan kepada Undang-Undang dan kepatuhan kepada Penguasa mengaburkan supremasi hukum yang merupakan salah satu unsur penting guna berjalannya konsep negara hukum. Dualisme kepatuhan yang cenderung bertolak belakang antara undang-undang disatu sisi, dengan penguasa disisi lain tidak dapat berlaku disuatu negara hukum kecuali kepatuhan kepada penguasa tersebut berlandaskan pada ketentuan hukum. Dengan kata lain tidak ada kepatuhan kepada selain hukum, kecuali kepatuhan tersebut atas dasar kepatuhan pada ketentuan hukum.

\subsection{Konsep Negara Hukum Indonesia dalam UUD 1945 Pasca Perubahan}

Perubahan UUD 1945 pada 1999-2002 diawali dengan konsensus tentang hal-hal yang tidak akan 
diubah dari UUD, diantaranya adalah Pembukaan/ Preambule yang tetap dipelihara sesuai dengan teks asli. Sehingga cita bernegara yang dituangkan dalam Alenia IV Pembukaan UUD tidak diubah dengan tetap berbunyi: "Kemudian dari pada itu untuk membentuk suatu Pemerintah Negara Indonesia yang melindungi segenap bangsa Indonesia dan seluruh tumpah darah Indonesia dan untuk memajukan kesejahteraan umum, mencerdaskan kehidupan bangsa, dan ikut melaksanakan ketertiban dunia yang berdasarkan kemerdekaan, perdamaian abadi dan keadilan sosial, maka disusunlah Kemerdekaan Kebangsaan Indonesia itu dalam suatu Undang-Undang Dasar Negara Indonesia, yang terbentuk dalam suatu susunan Negara Republik Indonesia yang berkedaulatan rakyat dengan berdasarkan kepada Ketuhanan Yang Maha Esa, Kemanusiaan Yang Adil dan Beradab, Persatuan Indonesia dan Kerakyatan yang dipimpin oleh hikmat kebijaksanaan dalam Permusyawaratan/Perwakilan, serta dengan mewujudkan suatu Keadilan sosial bagi seluruh rakyat Indonesia.

Dengan demikian, cita bernegara tetap mengandung empat tujuan yang meliputi; perlindungan, kesejahteraan, pencerdasan, ditambah dengan ketertiban dunia yang berdasar pada prinsip kemerdekaan, perdamaian abadi dan keadilan sosial (sebagai bingkai politik luar negeri Indonesia).

Konsep negara hukum Indonesia yang sebelum Perubahan hanya disebutkan dalam Penjelasan UUD, diletakkan dalam Pasal 1 Ayat (3) yang berbunyi "Negara Indonesia adalah negara hukum". Penempatan klausul tersebut dalam Pasal/Batang
Tubuh UUD sesuai dengan salah satu kesimpulan rapat PAD (Panitia Ad Hoc) I yang membahas perubahan bab I UUD 1945 tentang bentuk dan kedaulatan, yang berbunyi "sepakat menempatkan Indonesia sebagai negara hukum (rechtstaat)". ${ }^{14}$ Penggunaan istilah rechtstaat tidak diartikan bahwa konsep negara hukum yang dijalankan Indonesia merupakan penyesuaian terhadap ciri negara hukum yang terkandung dalam istilah tersebut. Istilah rechtstaat dalam hal ini merupakan lawan kata dari machstaat, suatu istilah yang menggambarkan pengelolaan negara berdasarkan kekuasaan.

Secara umum, dalam setiap negara yang menganut paham negara hukum, dapat dilihat bekerjanya tiga prinsip dasar, yaitu supremasi hukum (supremacy of law), kesetaraan di hadapan hukum (equality before the law), dan penegakan hukum dengan cara yang tidak bertentangan dengan hukum (due process of law). Juga ditemukan bahwa, pada setiap negara hukum akan terlihat ciri-ciri adanya :

1) Jaminan perlindungan HAM;

2) Kekuasaan kehakiman atau peradilan yang merdeka;

3) Legalitas dalam arti hukum, yaitu bahwa baik pemerintah/negara maupun warga negara dalam bertindak harus berdasar atas dan melalui hukum.

Adapun konsep negara hukum Indonesia memiliki ciri tersendiri. Ciri tersebut sejalan dengan tujuan berdirinya negara Indonesia, yang mencakup :

\footnotetext{
${ }^{14}$ Risalah Notulen Rapat PAH I tanggal 17 Mei 2000, dalam Valina Singka Subekti, Menyusun Konstitusi Transisi, (Jakarta: RajaGrafindo Persada, 2008), hlm. 129.
} 
1. Perlindungan terhadap segenap bangsa Indonesia dan seluruh tumpah darah Indonesia;

2. Pemajuan kesejahteraan umum;

3. Pencerdasan kehidupan bangsa; dan

4. Keikutsertaan dalam memelihara ketertiban dunia yang berdasarkan kemerdekaan, perdamaian abadi dan keadilan sosial.

Disamping itu, konsep negara hukum Indonesia juga dipengaruhi oleh Pancasila sebagai kumpulan nilai-nilai dasar yang diakui bersama bangsa Indonesia, dan menjadi landasan praktek kedaulatan rakyat, yakni Ketuhanan Yang Maha Esa; Kemanusiaan Yang Adil dan Beradab; Persatuan Indonesia dan Kerakyatan yang dipimpin oleh hikmat kebijaksanaan dalam Permusyawaratan/Perwakilan; serta Keadilan sosial bagi seluruh rakyat Indonesia. Dengan demikian, negara hukum Indonesia yang dijalankan haruslah senantiasa memperhatikan aspek ketuhanan, kemanusiaan, persatuan, permusyawaratan dan keadilan. Penegasan konsep negara hukum Indonesia menjadi penting agar ciri khas yang dimiliki bangsa ini tetap terpelihara.

Hal ini sejalan dengan pendapat seorang founding father, Soepomo, bahwa konsep negara hukum dilandasi oleh suatu Cita Negara Integralistik. ${ }^{15}$ Dalam rapat Badan Penyelidik Usaha-usaha Persiapan Kemerdekaan Indonesia (BPUPKI) tanggal 31 Mei 1945, Soepomo mengatakan: Jikalau kita hendak membicarakan tentang dasar sistem pemerintahan yang hendak kita pakai untuk Negara Indonesia,

15 Lihat Maria Farida, Ilmu PerundangUndangan, (Yogyakarta: Kanisius, 2007), hlm. 121. maka dasar sistem pemerintahan yang hendak kita pakai untuk Negara Indonesia, maka dasar sistem pemerintahan itu tergantung pada Staatsidee yang hendak kita pakai untuk pembangunan Negara Indonesia. Menurut dasar apa Negara Indonesia akan didirikan.

Pendapat Soepomo tentang Cita Negara Integralistik tersebut disetujui oleh rapat BPUPKI, yang kemudian dituangkan dalam pokok pikiran pertama Pembukaan UUD1945. Berdasarkan pendapat Soepomo tersebut, dapat diketahui bahwa latar belakang penentuan konsep negara hukum didahului dengan penentuan cita bernegara, yaitu cita negara integralistik, atau dalam istilah A. Hamid S. Attamimi ${ }^{16}$ diganti dengan 'cita negara kekeluargaan'/cita negara persatuan'.

Maka dapatlah disimpulkan bahwa konsep negara hukum sebagaimana tercantum dalam ketentuan Pasal 1 ayat (3) terkait erat dengan negara kesejahteran (welvaarstaat) atau paham negara hukum materiil sesuai dengan bunyi alenia keempat. Dalam hal ini, paham negara hukum tidak hanya mencakup penyelenggaraan negara saja, melainkan juga menyentuh kehidupan berbangsa dan bermasyarakat. ${ }^{17}$ Oleh karena itu dalam tataran implementasinya,

\footnotetext{
${ }^{16}$ Attamimi, Hamid S., Peranan Keputusan Presiden Republik Indonesia dalam Penyelenggaraaan Pemerintahan Negara: Studi Analisis mengenai Keputusan Presiden yang berfungsi Pengaturan dalam kurun Pelita I - Pelita IV, Disertasi Doktor Ilmu Hukum Tata Negara, Fakultas Pasca Sarjana, Universitas Indonesia, 1991.

17 Lihat Panduan Pemasyarakatan UUD 1945, cetakan kelima, (Jakarta: Sekretariat Jenderal MPR RI, 2008), hlm. 46.
} 
semakin aktif negara dalam melaksanaan konsep negara hukum akan mendukung dan mempercepat terwujudnya negara kesejahteraan di Indonesia. Sebaliknya, implementasi konsep negara hukum yang tidak sempurna atau setengah-setengah dapat menjauhkan Indonesia dari cita-cita pembentukannya sebagai sebuah negara.

\section{PENUTUP}

\subsection{Simpulan}

Konsep negara hukum yang dianut dalam UUD 1945 adalah negara hukum yang aktif/dinamis. Model negara hukum seperti ini menjadikan negara sebagai pihak yang aktif berorientasi pada pemenuhan dan perwujudan kesejahteraan rakyat sesuai dengan prinsip welvaarstaat, yang merupakan kebalikan konsp dan prinsip dari nachtwachternstaat atau negara penjaga malam. Sebab ciri yang melekat pada negara hukum Indonesia sejalan dengan tujuan berdirinya negara Indonesia, yaitu Perlindungan terhadap segenap bangsa Indonesia dan seluruh tumpah darah Indonesia; Pemajuan kesejahteraan umum; Pencerdasan kehidupan bangsa; dan Keikutsertaan dalam memelihara ketertiban dunia yang berdasarkan kemerdekaan, perdamaian abadi dan keadilan sosial.

Disamping itu, konsep negara hukum Indonesia juga dipengaruhi oleh Pancasila sebagai kumpulan nilai-nilai dasar yang diakui bersama bangsa Indonesia, dan menjadi landasan praktek kedaulatan rakyat, yakni Ketuhanan Yang Maha Esa; Kemanusiaan Yang Adil dan Beradab; Persatuan Indonesia dan
Kerakyatan yang dipimpin oleh hikmat kebijaksanaan dalam Permusyawaratan/Perwakilan; serta Keadilan sosial bagi seluruh rakyat Indonesia. Dengan demikian, negara hukum Indonesia yang dijalankan haruslah senantiasa memperhatikan aspek ketuhanan, kemanusiaan, persatuan, permusyawaratan dan keadilan.

\subsection{Saran}

Merujuk pada pendapat Hamid S. Attamimi yang menyarikan pendapat Soepomo atas paham negara integralistik, menunjukkan bahwa konsep negara hukum yang diberlakukan di Indonesia harus sejalan dengan cita memelihara persatuan bangsa. Maka akan cukup mudah untuk melakukan penilaian apakah implementasi konsep negara hukum di Indonesia sudah berjalan dengan baik atau belum, yaitu dengan melihat kesejajaran prakteknya dengan ketercapaian integritas bangsa Indonesia. Dengan demikian, arah perwujudan konsep negara hukum Indonesia hendaknya mengupayakan kesejahteraan rakyat sebagaimana dicantumkan dalam Pembukaan UUD 1945, dengan tetap memelihara integritas bangsa dalam NKRI.

\section{DAFTAR PUSTAKA}

$\underline{B u k u}$

A.B Kusuma, RM. 2009. Lahirnya Undang-Undang Dasar 1945 -Memuat Salinan Dokumen Otentik Badan Oentoek Menyelidiki Oesaha-Oesaha Persiapan Kemerdekaan-. Jakarta : Fakultas Hukum Universitas Indonesia. 
Asshiddiqie, Jimly. 2006. HTN dan Pilar-Pilar

Demokrasi. Jakarta: Konstitusi Press. 2010. Konstitusi dan Konstitusionalisme

Indonesia. Jakarta: Sinar Grafika

Budiardjo, Miriam. 2008. Dasardasar Ilmu Politik, Edisi Revisi. Jakarta: PT Gramedia Pustaka Utama.

Farida, Maria. 2007. Ilmu Perundang-Undangan. Yogyakarta: Kanisius.

Kelsen, Hans. 1971. General Theory of Law and State. New York: Russel and Russel. Terjemahan oleh Raisul Muttaqien. 2006. Teori Umum tentang Hukum dan Negara. Bandung: Nusamedia \& Nuansa.

Mahfud MD, Moh. 1999. Hukum dan Pilar-Pilar Demokrasi. Yogyakarta: Gama Media. 2003. Demokrasi dan Konstitusi di Indonesia. Jakarta: Rineka Cipta.

Republik Indonesia, Majelis Permusyawaratan Rakyat. 2005. Hasil Perubahan dan Naskah Asli UUD 1945, dalam Panduan Pemasyarakatan UndangUndang Dasar Negara Republik Indonesia Tahun 1945. Jakarta: Sekretariat Jenderal MPR RI.

2008.

Panduan

Pemasyarakatan UUD 1945, cetakan kelima. Jakarta: Sekjen MPR RI.

Singka Subekti, Valina. Menyusun Konstitusi Transisi, Pergulatan Kepentingan dan Pemikiran dalam
Proses Perubahan UUD 1945. Jakarta: PT RajaGrafindo Persada, 2008.

Thaib, Dahlan. Ketatanegaraan Indonesia. Yogyakarta: Total Media, 2009.

Wheare, K.C. Modern Constitutions. Oxford University Press. 1966. Terjemahan oleh Muhammad Hardani. Konstitusi-konstitusi Modern. Surabaya: Pustaka Eureka. 2003.

Makalah

Asshiddiqie, Jimly. Makalah Struktur Ketatanegaraan Indonesia Setelah Perubahan Keempat UUD 1945 disampaikan pada Seminar Pembangunan Hukum Nasional VIII Tema Penegakan Hukum Dalam Era Pembangunan Berkelanjutan. Denpasar, 2003.

Attamimi, Hamid S., Peranan Keputusan Presiden Republik Indonesia dalam Penyelenggaraaan

Pemerintahan Negara: Studi Analisis mengenai Keputusan Presiden yang berfungsi Pengaturan dalam kurun Pelita I - Pelita IV, Disertasi Doktor Ilmu Hukum Tata Negara, Fakultas Pasca Sarjana, Universitas Indonesia, 1991.

E Lotulung, Paulus. Kebebasan Hakim dalam Sistim Penegakan Hukum, Makalah Disampaikan Pada Seminar Pembangunan Hukum Nasional VIII Tema "Penegakan Hukum dalam Era Pembangunan 
Fiat Justitia Jurnal Ilmu Hukum Volume 5 No. 2 Mei-Agustus 2012, ISSN 1978-5186

Berkelanjutan"

Diselenggarakan

Oleh

Badan Pembinaan Hukum

Nasional Departemen
Kehakiman Dan Hak Asasi

Manusia RI. Denpasar, 14 18 Juli 2003. 